\title{
A SURVEY OF STUDIES ON THE PERFECT AND PLUPERFECT TENSES IN NORTH SAMOYEDIC LANGUAGES
}

\author{
Piret Klesment * $\quad$ Ago Künnap **
}

\begin{abstract}
There are too few devices in Samoyedic languages to express a completed/ accomplished action, so one of the ways to do it is just the use of perfect and pluperfect. Samoyedic languages have no common markers for moods and tenses, only a few of them occur in most of the languages mentioned. The Samoyedic system of conjugation is mainly based on verbal nouns, its mood and temporal markers mostly coincide with participle and gerund markers. The Tundra Nenets perfect is formed by means of the participle markers $-\{+(-m+)$, the pluperfect - by means of the compound marker $-\beta+(-m+) \ldots--1$. In Enets the marker $-b i$ as indicates an earlier meaning of the perfective participle that has disappeared by now, the pluperfect is formed by means of the compound suffixes $-\mathrm{b} i$ $(-\ldots i) \ldots-\backslash(-\backslash i)$. In Nganasan the marker -'V- expresses the past, more exactly the perfective preterit. The perfect has the compound marker $-b \mathrm{~V}(-h \mathrm{~V})+-t \mathrm{~V}(-\S \mathrm{V})$. Both perfect and pluperfect are used widely in the languages under observation, particularly in folkloristic texts. The formation and the use of perfect and pluperfect are mostly similar. As far as the Samoyedic participle marker $-b \mathrm{~V}$ is concernd, then G. J. Ramstedt (1952) refers to the Turkic perfect-gerund marker $-p(-y p,-u p)$ and to the Mongol preterit perfect marker -bai, -bei, -ba, -be.
\end{abstract}

Key words: North Samoyedic languages, perfect, pluperfect

\section{Introduction}

Perfect is a tense form of a verb that commonly belongs to the bounds of indicative but may also occur in other moods. On the other hand, perfectivity/imperfectivity is regarded

\footnotetext{
This article is supported by the Estonian Science Foundation, grant No. 7724. - On the evidence and mode of use of the perfect tense in South Samoyedic languages see Klesment (2004:110-115), cf. also Klesment (2002: 119-123).

* Piret Klesment: Aardla Str. 120-75, EE-50415 Tartu, Estonia. E-mail: piret.klesment@gmail.com.

** Ago Künnap: Department of Finno-Ugric Studies, Institute of Estonian and General Linguistics, Faculty of Philosophy, University of Tartu, Ülikooli Str. 18, EE-50090 Tartu, Estonia. E-mail: ago.kunnap@ut.ee.
} 
as a dimension of aspectuality. According to a generally accepted view aspectuality is a broader area, described as concurrence between two categories - grammar and lexis. Aspect calls for "bounds", i.e. a delimited and non-delimited action or situation may have the points of both the start and finish or, in other words, both are delimited.

According to H.-J. Sasse (2002: 203-205) aspectuality is two-dimensional. The first dimension is formed by perfectivity/imperfectivity. Some researchers incorporate also additional categories - stativity (habitual) and proceeding/progressive aspects. The other semantic dimension is made up by classical actions-art features. Any temporal characteristics of a situation are involved here, such as dynamicality, stativity, durativity, instantaneousness. Everything we know about aspect systems of the languages of the world indicates a close relationship between perfectivity and instantaneousness on the one hand and imperfectivity and stativity, on the other. The former is interpreted through the duration of obstructivity, the latter - through the duration of non-obstructivity.

Perfectivity/imperfectivity can be observed as morphological aspectuality. Perfective aspect describes an action as a whole, imperfective aspect views it via its internal structure. In other words, perfective aspect views an action as seen externally, the imperfective one as seen internally, or perfective action involves the time flow in the direction of a subject, in case of imperfective action the subject moves along the time flow. Perfectivity/ imperfectivity need not necessarily be clearly expressed in a sentence but may be hidden, e.g., in the context.

The 19th-century Indo-Europeists added another category to those two aspect categories - the perfect aspect, e.g., "present perfect" in English or in other languages in which the auxiliary verb "be" is combined with a perfective or imperfective verb. Perfectivity and imperfectivity are usually opposed because in most treatments the difference of habitual aspect from imperfectivity has not been emphasised, habituality could also be regarded as a semantic nuance of imperfectivity. Among other things, Indo-Europeistics distinguishes between the "nature of verb", that is internal or inborn and the "actions-art of verb" that is an external derivative mechanism and indicates which nature of verb has changed. (Sasse 2002: 203-205)

Likewise, B. Comrie (1976: 64) emphasises that the opposition perfect/non-perfect is not the same as that of perfectivity/imperfectivity. Perfect observes the achievement of the result of the situation via its duration. Since an incomplete action may also have consequences then it is possible to speak about an on-going situation to be completed eventually, i.e. a situation described via perfective meaning. 
Since preterital tenses - preterits and perfectives - evolved from the same source and in much the same way, having very similar semantic contents, a question arises about their difference. J. Bybee et al. (1994: 51-54) supposes that their difference consists in the way how they mutually influence semantic classes of imperfectivity and verb. Perfectives signal that the situation is viewed as bounded temporally. Perfective is the aspect used for narrating sequences of discrete events in which the situation is reported for its own sake, independent of its relevance to other situations. It is thus often used to refer to situations that occurred in the past. In many languages of the world the means for expressing the past are much broader than, e.g., for expressing the future. In the case of the past a certain role is played by the distance of the action expressed - whether it took place in the near or more distant past. To measure the past distance a variety of ways are used, e.g. the expressions related to the rotation of the earth on its axis - day, month, year, hour, minute, second, yesterday, four months ago etc. It has been underlined that there are too few devices in Samoyedic languages to express a completed/accomplished action, so one of the ways to do it is just the use of perfect and pluperfect.

The result of an action accomplished/ended earlier is expressed by means of perfect. At that the temporal relationship of perfect is not obligatory. The acknowledgement of the fact that the action took place is important. Often an unreal action is being expressed (the speaker has not eyewitnessed the action), in that case it is a case of absentive.

Since perfect is particularly rich in nuances, various researchers have adopted a variety of terms, e.g. anterior and tax. Anterior means preceding/foregoing. Anterior signals that the situation occurs prior to reference time and is relevant to the situation at reference time. Anteriors may occur with past or future tense marking. Anterior differs from perfective in that it would not be marked on several verbs in succession that are reporting a sequence of events but would only be used to show that some action is prior to the others in the narrative. (Bybee et al. 1994: 54) In her analysis of South Samoyedic Selkup, N. G. Kuznecova (1995: 135) uses the notion "tax".

Ö. Dahl argues that one of the principal characteristics of perfect is the fact that it is not used in the narrative (Dahl 1985: 113). Narrative preterit is generally not considered as perfect. According to J. Lindstedt (2000: 366) perfect is characterised by the following:

- a preterital situation must be more important than the current moment;

- perfect must be separated from the other past facts, i.e. it has to be non-narrative.

\section{Perfect and pluperfect in North Samoyedic}


Samoyedic langauages are part of Uralic languages. There are four North Samoyedic languages - Tundra Nenets, Forest Nenets, Enets and Nganasan - and one South Samoyedic language - Selkup (formerly there were two more, Kamass and Mator, which at present are extinct).

Samoyedic languages have no common markers for moods and tenses, only a few of them occur in most of the languages mentioned. Thus one can suppose that a uniform system of moods and tenses is lacking in those languages and the existing system comes from a rather recent date. The Samoyedic system of conjugation is mainly based on verbal nouns, its mood and temporal markers mostly coincide with participle and gerund markers. (see A.Kjunnap 1976: 170)

Researchers on Samoyedic languages present mainly two tenses of the indicative present/aorist and preterit. The number of actions expressed by preterit is rather large both in the semantic and morphological sense but due to insufficient means for expressing a perfective action various other devices are used. One of those is perfect, often also named preterit II by some of researchers in their works. The words reporting the distance from the moment of speaking are numerous and they include e.g. 'yesterday', 'long ago', 'earlier' etc. Often the distance from the moment of speaking depends on the context.

The $*$ ś-marked gerunds and participles mainly denote an acomplished action and this is why they are not only materially but also functionally close to the preterit with the *śs-marker (see A.Kjunnap 1976: 177).

\section{Tundra Nenets ${ }^{(1)}$}

T. Salminen (1997: 112) points out the fact that in the combination mood-tense an essential role is played by semantics. He indicates that the Tundra Nenets preterit suffix $\backslash$ functions only together with any of the definite moods - indicative, conjunctive, imperfective, probabilitative and narrative. This way the number of the tense-mood combinations reaches up to 20. Depending on their temporal relationships, the verbs can be divided into two groups. In case of instantaneous verbs, the near past can be expressed by the indicative aorist and the more distant past by the indicative preterit. In case of progressive verbs the present is expressed by the indicative aorist and the simple past by the indicative preterit. In the case of the subjunctive, the aorist expresses the conditional future and the preterit - the conditional past. In the narrative the aorist denotes perfect and

\footnotetext{
(1) Since there is only very scanty Forest Nenets material about the matter we are not going to observe this language.
} 
the preterit pluperfect tenses.

The Tundra Nenets perfect is formed by means of the participle markers $-\{+(-m+)$, e.g. ik + hibarim' ni-\{4-m' namd' 'I have not heard about that person' (Labanauskas 1974: 45). M. A. Castrén (1854) referred to the relationship of the named markers with the markers of the Kamass preterit -bi (-wi). Generally speaking, various researchers have rather vaguely determined the temporal background of the listed suffixes. Labanauskas (1974: 47-48) argues that the suffix $-\{+(-m+)$ has no aspectual meaning because it cannot be used in extemporal forms. Thus the markers under observation can be regarded as temporal, not aspectual. Consequently, the tense form that possesses above mentioned markers has either a narrative or perfective meaning.

The Nenets pluperfect is formed by means of the compound suffix $-\beta+(-m+) \ldots-$ l, e.g. lerta- $\beta$ e-don-I 'sie hatten gemacht (they had made)'. In some cases pluperfect may overlap with the perfective participle, therefore the context becomes important. For the reasons named last the Tundra Nenets pluperfect as a preterit tense has often not been indicated separately. (Labanauskas 1982: 126,134)

Labanauskas (1982: 128-129) has proposed the incidences with the pluperfect:

- It denotes an action that took place long ago or an action that began before the beginning of some other action, e.g. from folklore: Яля' тюку яля' пя янцгкуни манэсарңаманзь, нули' намгэхэрт нивы ерев'. Нопой нохокохова иб' еремысь, тикыехэртами ңаблараравы' 'I looked my traps over today and not a thing was in them. Only an arctic fox was trapped but it had also been bitten'.

- Pluperfect denotes an action that took place long ago but whose result has a logical relationship with what is being said at the moment of speaking, e.g. in folklore: Мань Ябта саля' ерв' нюм', сяхава' пыр нисяв хадвэнась. Теда' ань' мань сит хадаңсум' 'I am the son of your master Jabta salja, whom you killed long ago. Now I am going to kill you'.

- Pluperfect may sometimes occur as an absentive and in that case describe an action that the speaker had heard from others, e.g. in folklore: Тикы мань нисявась. Муно' погна нисяв намбвы, мамыць: Носитэтана ацькытане 'It was my father. He had heard the people say, At Nositeta's place there lives a youth'.

- Pluperfect is used in fairy tales or stories about old times that may have had some historical evidence as well as for describing reminiscences, e.g. in folklore: Нисяв танясав', ягусав', сэва 'н тяхад небяв си 'м вадавысь, не Тасиний вадбавысь. Си'в тидяков, сив' Тасиний си'м вадавыць. Ябтудадо' недяв харта тэтась, ылька 
mыгу хадавэдась 'Whether I had or not any father [I don't know], from the time I can remember my mother had brought me up, a Tasinij woman, herding reindeer. I was brought up my seven uncles, seven Tasinijs. My mother, a reindeer breeder was killed by a giant Tungus when she had gone to fetch clothes of elk hide'.

\section{Enets}

Beside the common preterit (with the marker -ś), I. P. Sorokina (1980: 212) presents another preterit tense. When the common preterit expresses an action or event that took place in the past, having no relationship to the present, then the other preterit denotes an action or event that took place in the past but has a direct outlet at the moment of speaking/in the present. The suffix $-b i$ is the marker of the latter and it is placed between the stem of the verb and personal endings and is called preterit II. K. Labanauskas (1974: 47) views the marker - $b i$ as indicating an earlier meaning of the perfective participle that has disappeared by now.

The preterit forms with the named marker are sufficiently productive in Enets, expressing an action completed in the past but which the speaker did not eyewitness, and thus they are mainly used in the narrative. The fact that the narrator did not witness the reported action is not really important; what is important is the perception of the result of that past action in the present. This is the latter that I. P. Sorokina (1980: 213) considers as the criterion of perfect, e.g. tea $\boldsymbol{k} \boldsymbol{a}-\boldsymbol{b i}$ 'The reindeer had died already'; bu kod' ni§ sumo-bi- $\S$ ' 'He had fallen off from the sledge'; detču salba kani-bi 'The ice has run from the Yenisey' (cf. also Künnap 2002: 39-48).

I. P. Sorokina (1980) also refers to another option in Enets, in which case a past action is described while the speaker never eyewitnessed anything. This is a form with the compound marker $-b i \ldots-s i$ and the form has no temporal meaning any more but a modal one. Such a marker is called a marker of indirect (narrative) by I. P. Sorokina. Narrative describes an action in which the speaker is not an on-looker. In the latter construction the temporal background is explained via adverbials of time 'yesterday', 'today', 'tomorrow' etc. E.g. bu to-bi-śs 'He seems to have come already'; bu čenuju čukči oburu kolta-bi-ś 'She seems to have washed all the things yesterday'. (Sorokina 1980: 213)

Beside the above construction there are also other uses in which the eyewitnessing/no eyewitnessing of an acomplished action has no significance, and here it is possible to speak about perfect. Two-aspective nature of preterit II has been noted also by other researchers. The two-aspective nature is explained by the fact that both 
Enets and other Samoyedic languages have only a limited number of means to express a completed action and so preterit II makes up for the shortage.

The Enets pluperfect is formed by means of the affixes $-\mathrm{b} i(-\ldots i) \ldots-\backslash(-\backslash i)$, e.g. Madu dial. s2robidali 'er hatte geknüpft (he had bound)'. Some researchers regard both Nenets and Enets pluperfect as a narrative. (Labanauskas 1982: 134)

G. N. Prokof'ev has seen the markers $-\mathrm{bi} /-\ldots i$ as the constituents of a supposing/ anticipating mood. According to N. M. Tereščenko (1979) the named markers express an action that the speaker personally has not witnessed, or an accidental, unexpected action. T. Mikola calls them markers of the aorist narrative. I. P. Sorokina (1980: 213), on the other hand, regards them as indicative perfect. In the case of the perfect under discussion it is not important for the speaker if s/he was an eyewitness to the action or not, it is important only to state the concrete action's result as it has been preserved up to the moment of speaking.

A definite place for the forms under discussion has not been found in the Enets system of tense and mood. Earlier K. Labanauskas (1982: 130-131) has also stated that those were preterit forms of the oblique mood, later, however, he has analysed them as pluperfect because he did not find any formants for expressing unreal action there.

Instances of use of the Enets pluperfect (132):

- Pluperfect expresses an accomplished or on-going action that precedes a prior action in the past, e.g. Madu dial. kar2 ka 'arana' no' kaniba li oddoho§o, kuorida' mov2 $k a$ 'arabißudi 'we went to load the fish off the boat but it appeared that the fishermen had loaded it off already'.

- An action that was completed long ago but which has a logical relationship to the present, e.g. Madu dial. kuhuan2 in2ro ãkkã dado daßubilinu', todi totorio tād2ddo 'some time ago your elder brother travelled here, and so will you one day'.

- An action that was completed long ago and that is known only through indirect sources (absentive), e.g. Madu dial. kan2\̄̌ s+rahan2kka s2§oko kadabi \i, čuku $2 n c ̌ 2 o$ ' $t 2 j n o$ ' náda' 'last winter they had caught many arctic foxes, all of them say so'.

\section{Nganasan}

Nenets uses the participle of completed action to express an action without eyewitnesses (absentive, renarrative). Based N. M. Tereščenko (1979: 220), the named forms in Nganasan emerged in a different way, i.e. it does not apply the participle of a completed action, there are special markers of the reported information (narrative) -баqху / -бяхы / 
-хуачху / -хуамбу with phonetic variants, e.g. МунуqкЕнду', сыты ченыбяqхы 'Не is said to have known'.

In the case of Nganasan, K. Labanauskas (1975) draws attention to the element -'Vwhich takes place inside the verb between the stem and personal endings and occurs in the perfective preterit forms of indefinite time. This marker occurs in both the objective and subjective conjugations and depends on no other aspects denoting perfectivity. Thus K. Labanauskas concludes that it is an independent marker. N. M. Tereščenko (1979) has indicated that the forms with that marker look very much like the present type but no one uses them as present. In comparing verb forms to this particular marker in the indicative present and future, K. Labanauskas concludes that it is still a marker expressing the past, more exactly with the perfective preterit, e.g. kona- ' $a$ 'he went', s'ser + +- 'Eò 'he drank'. When comparing the preterit with that particular marker to other, more familiar preterit markers, the following regularity appears with the marker - V-: $m+$ - Eò 'he was doing (now)'; the preterit with the marker $-s \mathrm{~V}-,-d(j) \mathrm{V}-$ : $m e-s$ ' $e$ 'he was doing (in the past)'; the perfect with the marker $-b \mathrm{~V}(-h \mathrm{~V})+-t \mathrm{~V}(-\S \mathrm{V})$ : mej-hà + 'he seems to have done' (Labanauskas 1975: 197).

Based on the examples above the preterit with the marker - V- seems to express an action that was recently completed and that is topical at the moment of speaking. In the case of Enets, I. P. Sorokina (1980) pointed out namely the topicality of a past action for the present as a criterion of perfect. Indeed, the marker of the Nganasan perfective preterit differs from perfect by the fact that it lacks the clarity/obvious nuance that is typical of perfect. The marker under discussion is regarded as originating from an earlier aorist marker *-(C)t $\mathrm{V}$ - that began to be used due to shortage of means for expressing a completed action.

K. Labanauskas (1975: 197-198) suggests the markers of the Nganasan perfect in the forms of $-b \mathrm{~V}(-h \mathrm{~V})+-t \mathrm{~V}(-\S \mathrm{V})$, e.g. $n_{s} \mathrm{q} h u m-h a$-tu 'he seems to have become bad', $b \hat{u}-b a-t a-\S \mathrm{E}$ 'he seems to have left'.

\section{Conclusion}

Both perfect and pluperfect are used widely in the languages under observation, particularly in folkloristic texts.

Perfect and pluperfect are characterised by a nuance of the so called instance of clarity that the words like 'didn't I', 'as is well-known', 'evidently' etc. help to emphasise. In addition to clarity, in the use of perfect and pluperfect it is important that a past event or 
accomplished action had some traces also in the present. It is not important though that the speaker should have been an eyewitness to the reported event. It is just the result perceived in the present that I. P. Sorokina (1980) regards as a criterion of perfect.

The formation and the use of perfect and pluperfect are mostly similar in the languages under observation. In case of pluperfect in Nenets and Enets A. Künnap (1994: 114) has indicated that the sibilant preterit marker comes from the form $* \mathrm{~V}-s \mathrm{~V}$ of the auxiliary 'be'.

As far as the Samoyedic participle marker $-b \mathrm{~V}$ is concerned, then G. J. Ramstedt (1952: 132-133) refers to the Turkic perfect-gerund marker $-p(-y p,-u p)$ and to the Mongol preterit perfect marker $-b a i,-b e i,-b a,-b e$, that can be found only in the indicative forms. Thus it is a perfective aspect with preterit markers.

\section{References}

Bybee, J., R. Perkins, W. Pagliuca. 1994. The Evolution of Grammar. Tense, Aspect, and Modality in the Languages of the World. [M] Chicago and London.

Castrén, M. A. 1854. Grammatik der samojedischen Sprachen. [M] St. Petersburg.

Comrie, B. 1976. Aspect. [M] Cambridge.

Kjunnap, A. 1976. K probleme proishoždenija pokazatelej naklonenij i vremen v ural'skih jazykah. [J] Sovetskoe finno-ugrovedenie. No. 3. Tallinn.

Klesment, P. 2002. Indikatiivi aegadest lõunasamojeedis võrrelduna mõnede mitteuurali lähinaaberkeeletega. [J] Fenno-Ugristica. Vol. 24. Tartu.

Klesment, P. 2004. On the Incidence and Mode of Use of the Perfect Tense in South Samoyed Languages in Comparison to Altaic Languages. [J] Fenno-Ugristica. Vol. 26. Tartu.

Kuznecova, N. G. 1995. Grammatičeskie kategorii južnosel'kupskogo glagola. [M] Tomsk.

Künnap, A. 1978. System und Ursprung der kamassischen Flexionssuffixe II. Verbalflexion und Verbalnomina. [J] Mémoires de la Société Finno-Ougrienne. Vol.164. Helsinki.

Künnap, A. 1994. On the use of the verbal noun *V-s'V 'being' in Samoyed languages. [J] Linguistica Uralica. No.2. Tallinn.

Künnap, A. 2002. Main Language Shifts in the Uralic Langauge Group. [M] LINCOM Studies in Asian Linguistics Vol.45. München.

Labanauskas, K. 1974. Neneckij perfekt. [J] Sovetskoe finno-ugrovedenie. 10. Tallinn.

Labanauskas, K. 1975. Prošedšee vremja soveršennogo dejstvija v nganassanskom jazyke. [J] Sovetskoe finno-ugrovedenie 11. Tallinn.

Labanauskas, K. 1982. K izučeniju prošedših vremen neneckogo i èneckogo jazykov. [J] Sovetskoe finno-ugrovedenie. 18. Tallinn.

Lindstedt, J. 2000. The perfect - aspectual, temporal and evidential. [A] In Ö. Dahl (ed.): Tense and aspect in the langauages of Europe. [C] Berlin \& New York.

Ramstedt, G. J. 1952. Einführung in die altaische Sprachwissenschaft II. Formenlehre. [J] Mémoires de la Société Finno-Ougrienne. Vol. 104. Helsinki.

Salminen, T. 1997. Tundra Nenets Inflection. [J] Mémoires de la Société Finno-Ougrienne. Vol. 227. Helsinki.

Sasse, H.-J. 2002. Recent activity in the theory of aspect: Accomplishments, achievements, or just non-progressive state? [J] Linguistic Typology. Vol. 6(2). Berlin - New York.

Sorokina, I. P. 1980. Èneckij perfekt. [J] Sovetskoe finno-ugrovedenie. 16. Tallinn.

Tereščenko, N. M. 1979. Nganassanskij jazyk. [M] Leningrad. 